\title{
Małgorzata Pacholarz
}

Katedra Bibliotekoznawstwa i Informacji Naukowej

Uniwersytet Łódzki

e-mail: malgorzatapacholarz@interia.pl

\section{T Janina Porazińska - autorka jeszcze popularna czy już zapomniana? Z dziejów edytorstwa książek pisarki ${ }^{1}$}

\author{
DOI: http://dx.doi.org/10.18778/0860-7435.21.02
}

\begin{abstract}
ABSTRAKT: Celem niniejszego artykułu jest zaprezentowanie edytorskich losów książek Janiny Porazińskiej na rynku wydawniczym i dzięki temu udzielenie odpowiedzi na pytanie, czy Porazińska jest pisarką jeszcze popularną czy już zapomnianą. Część pierwsza artykułu przybliża postać artystki oraz nakreśla rozwój jej warsztatu literackiego na przestrzeni całego życia. Ponadto, zarysowuje dotychczasowy stan badań dotyczący osoby i twórczości Porazińskiej. Część druga zawiera omówienie dziejów wydawniczych książek pisarki; prezentuje statystyczne dane dotyczące nowych tytułów i ich kolejnych wydań, opatrzone bbliologicznym komentarzem, jak również zawiera próbę periodyzacji popularności twórczości autorki Szewczyka Dratewki. Ponadto, omawia kwestie instytucji wydawniczych i ilustratorów zaangażowanych w pracę nad książkami Porazińskiej. Całość ukazuje fenomen literacki pisarki, której książki obecne są na rynku wydawniczym od 103 lat.
\end{abstract}

SŁOWA KLUCZOWE: Janina Porazińska, wydawnictwa polskie, polska literatura dla dzieci

Naturalną koleją rzeczy jest, że wszystko, co stare, zostaje wyparte przez nowe. Tak dzieje się chociażby z tendencjami w modzie czy architekturze. To samo prawo dotyczy również szeroko rozumianej kultury - stare pokolenie

\footnotetext{
${ }^{1}$ Niniejszy artykuł został oparty na pracy magisterskiej M. Pacholarz (2014).
} 
twórców (muzyki, sztuki, literatury itp.) „ustępuje miejsca” młodej generacji. Pewna część odchodzących artystów zostaje zapomniana, podobnie jak ich dzieła, sława innych natomiast wytrzymuje próbę czasu i trwa przez dziesiątki - a nawet setki - lat. Jest jednak jeszcze jedna grupa twórców. Stanowia ją Ci, których dzieła i sama osoba za życia cieszyły się ogromna popularnością, natomiast po śmierci wprawdzie nie zapomniano o nich zupełnie, bo sa w jakimś stopniu (raczej mniejszym, niż większym) obecni w kulturze, jednak zanikła w społeczeństwie świadomość ich dawnej sławy. Przykładem takiego twórcy wydaje się być pisarka dla dzieci Janina Porazińska. Można doszukiwać się przyczyn zaistnienia tego stanu rzeczy (np. poruszana przez autorkę niemodna już tematyka wiejskiego życia czy gwarowa stylizacja języka), jednak bardziej wartościowe wydaje się prześledzenie dziejów jej twórczości i na ich podstawie udzielenie odpowiedzi na pytanie, czy Porazińska jest autorką nadal popularną czy już zapomnianą.

\section{Biogram}

L Janina Porazińska urodziła się w Lublinie 29 września 1882 r. (Ratyńska, 2011, s. 11), a nie jak wskazuja niektóre źródła - 29 września 1888 r. (Daniszewski, 1989, s. 5), jako córka Edwarda Porazińskiego i Heleny z Saryusz-Bielskich. Coroczne wakacje, które jako dziecko spędzała u dziadków we wsi Chrusty, miały znaczący wpływ na jej twórczość - często sięgała po ludowe motywy, interesowal ja świat przyrody i zwierząt oraz wiejskie tradycje (Pietrzak, 1996, s. 27). Nauki pobierane na pensji u Natalii Porazińskiej w Warszawie pozwoliły pisarce ukończyć szkołę średnią. Jej dalsza edukacja objęła dwuletnie kursy im. A Baranieckiego w Krakowie oraz trzyletnie studia na Wydziale Przyrodniczym Uniwersytetu Jagiellońskiego (Frycie \& Ziółkowska-Sobecka, 1999, s. 308). Po ich ukończeniu w 1911 r. pisarka osiedliła się w Warszawie i zajęła wyłącznie pracą literacką.

Porazińska zadebiutowała utworem $Z$ życia kwiatów, który ukazał się w 20 numerze czasopisma „Wędrowiec” z 1903 r. (Czachowska \& Szałagan, red., 1999). Stało się to jednocześnie początkiem jej długoletniej współpracy $\mathrm{z}$ wieloma periodykami. Nieliczne teksty autorki pojawiały się w prasie dla dorosłych (np. „Tydzień”, „Zgoda”), jednak to w pismach dla dzieci i młodzieży można było odnaleźć najwięcej utworów Porazińskiej. Ogłaszała swoje teksty w: „Przyjacielu Dzieci” (1905-1906, 1911-1914), „Wieczorach Rodzinnych” (1905-1913), „Moim Pisemku” (1906-1924), „Promyku” (1909-1910), „Promyczku” (1910) i „Rozrywkach dla Dzieci i Młodzieży” (1911) (Tamże). Publikowała w tych czasopismach zarówno drobne wierszyki, opowiadania, powiastki, krótkie obrazki sceniczne, ale także dłuższe utwory 
(dramaty, bajki) drukowane w kilku lub kilkunastu kolejnych numerach. Spośród wieloodcinkowych tekstów po kilku latach niektóre z nich pojawiły się na rynku księgarskim, m. in.: komedyjka Krzywda nagrodzona (1913), utwór dramatyczny Matgosia w górach (1917), bajki: Przygoda koziotka (1918), Cqarodziejska fujarka (1923) i Zaśnij oczko! (1924) (Pacholarz, 2014).

Debiutem książkowym Porazińskiej była opublikowana w 1912 r. baśń sceniczna $W$ noc wiosenna (Tylicka \& Leszczyński, red., 2002). To właśnie utwory dramatyczne są dominującym rodzajem literackim w poczattkowym okresie twórczości pisarki. Spośród 18 opublikowanych do 1924 r. tytułów najwięcej (8) stanowiły utwory dramatyczne (komedyjki, baśnie i bajki przeznaczone do wystawienia na scenie oraz obrazki sceniczne), pozostałe (po 5) to teksty liryczne (poematy, zbiory wierszy) oraz prozatorskie (bajki, opowiadania, baśnie) (Pacholarz, 2014). Widać więc, że Porazińska próbowała sił w różnych rodzajach i gatunkach, co pozwoliło jej udoskonalić warsztat i ostatecznie ukształtować swój literacki styl.

W czasie I wojny światowej podjęła pisarka dwie ważne inicjatywy: współtworzenie elementarzy i czytanek do nauki języka polskiego oraz założenie w 1917 r., wspólnie z Różą Brzezińska, pisemek dla dzieci „Płomyk” i „Płomyczek” (była ich redaktorką w latach 1927-1934). W okresie międzywojennym do wspomnianej działalności dodać należy zorganizowanie własnych periodyków dziecięcych - „Słonko” i „Poranek” (Tamże) oraz sukcesy wydawnicze (24 nowe tytuły). Wspomniany 1924 r. okazał się ważny w twórczym życiu pisarki. Ukazało się najwięcej nowych tytułów w stosunku do poprzednich lat - aż 6 - a wśród nich trzy ostatnie w jej dorobku utwory dramatyczne. Ponadto, opublikowano dwie - jak się później okaże niezwykle popularne - książki: zbiór poezji $W$ Wojtusiowej ižbie z nieśmiertelną Bajka iskierki oraz, cieszącą się ogromna poczytnością, obszerną baśń Kichuś Majstra Lepigliny.

Twórczość Porazińskiej po 1924 r. opiera się na utworach lirycznych i prozatorskich, które tworzyła równocześnie lub na przemian. Nie można wskazać konkretnych okresów ani dat pisania tylko prozy lub tylko poezji. Wnioski wyciagnięte jedynie na podstawie publikowanych książek mogłyby nieco wypaczać prawdę. Na przykład: w latach 1933-1947 ukazały się prawie wyłącznie same utwory prozatorskie, jednak świadomość, że w tym samym czasie Porazińska umieszczała w stworzonym przez siebie pisemku „Słonko” liczne utwory wierszowane dopełnia obraz jej ówczesnej działalności twórczej. Wyliczenia statystyczne wskazuja na przewage książek pisanych proza, jednak zarówno wśród poezji, jak i prozy można znaleźć tytuły poczytne i wielokrotnie wznawiane (Tamże). 
Okres powojenny to dalsza współpraca Porazińskiej z czasopismami dla najmłodszych („Iskierki”, „Świerszczyk”) oraz apogeum jej twórczości, na które wskazuje liczba 21 pierwodruków wydanych w przeciagu zaledwie 10 lat oraz 115 wznowień książek opublikowanych w latach 50. i 60. (Tamże). Wtedy również ukazały się opracowane przez nią tłumaczenia książek dla młodzieży autorów skandynawskich.

Na twórczy dorobek Porazińskiej składa się bogaty wachlarz gatunków wśród tworzonych przez nią utworów wierszowanych należy wymienić: ludowe kołysanki, bajeczki liryczne, wiersze taneczne, poematy dziecięce (Frycie, red., 1982). Nieco bogatszy jest repertuar tekstów pisanych prozą: baśnie, bajki, podania, legendy, opowiadania, powieści, wspomnienia (Białek, 1963, s. 199; Białkowska, 1957, s. 42).

Janinę Porazińską i jej twórczość uhonorowano wieloma nagrodami, wyróżnieniami i medalami. Zmarła 2 listopada 1971 r. w Warszawie (Białek, 1987, s. 277).

\section{Dotychczasowe badania nad twórczością Janiny Porazińskiej}

L Janina Porazińska i jej twórczość od poczatku były - i są nadal - przedmiotem zainteresowania wielu badaczy: teoretyków literatury, krytyków oraz metodyków pracy z tekstem. W latach 1923-2010 w periodykach ukazało się co najmniej 108 opracowań dotyczących pisarki i jej utworów (na podstawie badań własnych opartych głównie na Polskiej Bibliografii Literackiej za lata 1944-2000).

Autorce niniejszego tekstu nie udało się ustalić, czy do 1918 r. pojawiły się w prasie artykuły lub chociażby wzmianki o samej autorce lub utworach przez nią napisanych, co nie jest jednak jednoznaczne z brakiem takowych. Natomiast pewne jest, że w dwudziestoleciu międzywojennym co najmniej cztery periodyki zamieszczały teksty dotyczące twórczości Porazińskiej. „Rocznik Literacki” i „Nowa Książka” - pisma o charakterze literackim publikowały notki wydawnicze oraz teksty krytyczne, w „Teatrze Ludowym” ukazywały się recenzje, a w „Wychowaniu Przedszkolnym” - artykuły przekrojowe o twórczości autorki $W W$ ojtusiowej įbie.

Po II wojnie światowej widać wyraźny wzrost liczby badaczy zajmujących się życiem i dorobkiem literackim Porazińskiej oraz ich publikacji na te tematy. Artykuły pojawiały się w licznych i różnorodnych czasopismach: literackokulturalnych (gdzie zamieszczano recenzje, polemiki, prace krytyczne), oświatowych (w których przybliżano osobę i twórczość pisarki) oraz w prasie codziennej (pojawiały się w niej wywiady z autorką i recenzje książek). W tym 
okresie w prace nad życiem i dorobkiem literackim Porazińskiej najbardziej zaangażowali się: Krystyna Kuliczkowska, Halina Skrobiszewska oraz Józef Zbigniew Białek.

Krystyna Kuliczkowska i Halina Skrobiszewska koncentrowały się głównie na twórczości pisarki, ogłaszając recenzje pojawiających się nowych książek. Trzeci z wymienionych badaczy - historyk literatury Józef Zbigniew Białek podjął się opracowania obszerniejszego studium dotyczącego Porazińskiej. W opublikowanej w 1963 r. pracy jego autorstwa pt. Janiny Porazińskiej poezja dla dzieci dokonał charakterystyki chronologicznie zaprezentowanych zbiorów wierszy pisarki oraz ich analizy pod względem tematycznym, formalnym, językowym oraz artystycznym. Przez wiele lat była to jedyna poważniejsza praca traktująca o twórczości autorki $W W$ ojtusiowej iz̧bie.

Po śmierci Porazińskiej (1971) nie zmalało zainteresowanie jej osobą i dorobkiem literackim. W prasie publikowano często życiorysy, notki biograficzne oraz wspomnienia $z$ nia związane, a utwory rozpatrywano przez pryzmat różnych aspektów. Twórczościa pisarki nadal zajmowała się H. Skrobiszewska, publikując na łamach pism kulturalno-literackich. Do grona badaczy działalności pisarskiej Porazińskiej dołączył Brunon Daniszewski, który w 1989 r. opracował dziesięciostronicowa publikacje pt. Janina Porazińska pisarka dla dzieci $i$ młodzie ży. Zaprezentowal w niej biogram oraz dorobek twórczy autorki, a dodatkowo - jako pierwszy - dokonał zestawienia bibliograficznego książek pisarki (pierwodruków wraz z kolejnymi wznowieniami), które ukazały się do 1957 roku. Spisu tego nie opatrzył komentarzem. Podobnego opracowania podjęli się 40 lat później autorzy słownika Współcześni polscy pisarze $i$ badacze literatury. Stownik biobibliograficzny. T. 6 pod redakcja Jadwigi Czachowskiej i Alicji Szałagan opublikowanego w 1999 roku. W tym przypadku datą graniczną był rok 1997. Wykazu tego również nie uzupełniono o bibliologiczną analizę.

Obecnie, w XXI w., badacze nadal są zainteresowani życiem i twórczościa Janiny Porazińskiej. Najważniejszą jest Bożena Olszewska, której liczne artykuły stały się przyczynkiem do przygotowania obszernej monografii pt. „I w sto koni nie dogoni...”. O życiu i sztuce pisarskiej Janiny Porazińskiej (2007). Twórczość autorki W W ojtusiowej į̧bie została w niej ukazana w kontekście literaturoznawczym. W roku 2014 opublikowano drugi tom pracy Bożeny Olszewskiej pt. „Kto mi dat skrzydła...”. O życiu i dziatalności Janiny Porazińskiej (2014). O wznowieniach książek autorki Szewczyka Dratewki w XXI w. pisała także Grażyna Lewandowicz-Nosal w artykule opublikowanym w „Wychowaniu w Przedszkolu” (2012). 


\section{Cel pracy. Wykorzystane źródła}

L Prześledzenie dotychczasowego stanu badań pozwala stwierdzić, że na temat twórczości Porazińskiej wypowiadali się głównie literaturoznawcy, pominięty został natomiast prawie zupełnie aspekt bibliologiczny, ograniczony zaledwie do opracowania zestawień bibliograficznych nie poddanych głębszej analizie. Zasadne wydaje się więc podjęcie takiej próby i prześledzenie dziejów wydawniczych twórczości autorki $S_{\text {zew } e q y \text { ka }}$ Dratewki, której ponad stuletnia obecność na rynku wydawniczym jest swoistym fenomenem.

Celem artykułu jest zaprezentowanie edytorskich losów książek Janiny Porazińskiej na rynku wydawniczym. Przedstawione zostaną statystyczne dane dotyczące nowych tytułów i ich kolejnych wznowień, opatrzone bibliologicznym komentarzem. Ponadto, przybliżona zostanie kwestia instytucji wydawniczych i osób ilustratorów zaangażowanych w pracę nad książkami Porazińskiej. Odtworzenie dziejów wydawniczych twórczości pisarki umożliwiły wykorzystane źródła drukowane: Polska Bibliografia Literacka za lata 19451988, Wspótcześni polscy pisarze i badacze literatury. Stownik biobibliograficzny. T. 6 pod redakcja Jadwigi Czachowskiej i Alicji Szałagan (Warszawa 1999), Janina Porazinska pisarka dla drieci i młodzieży Brunona Daniszewskiego (Toruń 1989), źródła dostępne online: katalogi - Biblioteki Narodowej, Biblioteki Publicznej m. st. Warszawy (Muzeum Książki Dziecięcej) i miejskich bibliotek publicznych w Lodzi, Polska Bibliografia Literacka za lata 1988-2000, strony WWW wydawnictw oraz księgarń internetowych, a także bezpośredni kontakt e-mailowy z kilkoma oficynami (Nasza Księgarnia, Zielona Sowa, Siedmioróg). Najważniejszym źródłem było jednak przebadanie z autopsji 153 egzemplarzy książek, prowadzone na podstawie księgozbiorów: Biblioteki Uniwersytetu Łódzkiego, Wojewódzkiej Biblioteki Publicznej im. Marszałka Józefa Piłsudskiego w Lodzi (Muzeum Książki Dziecięcej) oraz filii Miejskiej Biblioteki Publicznej Łódź-Śródmieście im. Andrzeja Struga.

\section{Nowe tytuły}

L Na wydawniczy dorobek Janiny Porazińskiej składają się książki autorskie, współautorskie oraz przetłumaczone z innych języków.

Za życia pisarki ukazało się 77 tytułów autorskich, jednak trzeba zaznaczyć, że sześć z nich to utwory, które pojawiły się we wcześniejszych jej publikacjach (np. opowiadanie Agata nogq zamiata wydane samodzielnie w 1953 r. pochodzi ze zbioru O dwunastu z rapiecka z 1946 roku). Z podobną sytuacją mamy do czynienia po śmierci Porazińskiej - dzięki inicjatywie oficyn (m. in. Naszej Księgarni, Krajowej Agencji Wydawniczej i Literatury) ukazało się sześć utworów, których teksty zaczerpnięte zostały z książek opu- 
blikowanych za życia pisarki. Przykładem jest baśń Szewczyke Dratewka (wchodząca w skład wydanego w 1961 r. zbioru Czarodziejska ksiega), która w 1973 r. „usamodzielniła się” na rynku wydawniczym. Obok 77 książek autorskich w dorobku Porazińskiej znajduje się 10 tytułów współautorskich (sa to głównie czytanki i elementarze) oraz 6 książek przetłumaczonych przez nia z innych języków. Łącznie daje to liczbę 93 tytułów.

W latach 1912-1918, czyli od ksiażkowego debiutu pisarki do końca epoki Młodej Polski, ukazało się 11 jej nowych tytułów, wśród których obok 10 autorskich znalazło się pierwsze opracowanie współautorskie - Ziarno. Caytanki pierwsze dla dorostych - wydane w 1916 r., a powstałe w wyniku współpracy Porazińskiej z Rozalią Brzezińską. W omawianym początkowym okresie twórczej pracy pisarki istotne były lata 1917 i 1918, które można traktować jako krótką fazę intensywnej działalności literackiej - ukazały się wówczas odpowiednio - 5 i 3 nowości. Siedem pierwszych lat okazało się więc bardzo owocnymi dla autorki $W W$ ojtusiowej iz̨bie.

W pierwszych latach dwudziestolecia międzywojennego (1919-1922) światła dziennego nie ujrzała ani jedna nowa pozycja Porazińskiej, jednak po tej czteroletniej przerwie, od roku 1923, rozpoczyna się 40-letni okres prawie nieprzerwanego pojawiania się nowych książek pisarki na rynku wydawniczym. W okresie międzywojnia kontynuowała ona prace nad utworami współautorskimi, których wówczas wydano 7. Nigdy później Porazińska nie zaangażowała się aż tak bardzo w pracę nad tego typu pozycjami. Ponadto, publikowała dużo książek autorskich - w latach 20. i 30. ukazało się odpowiednio - 12 i 13 nowych tytułów, co daje 25 książek w ciagu 17 lat (1923-1939). Rekordowy w tym okresie był, wspomniany wcześniej, rok 1924, w którym wydano 6 książek. Wiele z opublikowanych wówczas pierwodruków jest nadal obecnych na rynku wydawniczym, na co wskazuja ich liczne wznowienia. Do takich książek zaliczyć należy (obok przytoczonych powyżej $W$ Wojtusiowej izbie i Kichus Majstra Lepigliny), m. in. poematy: Wesele Matgorzatki, Kopciuszek, Jaś i Kasia czy opowiadania: Balbina i gawron, Maciuś Skowronek, Kozucha Kłamczucha.

Trudne lata wojny nie okazały się zupełnie bezowocne w twórczej pracy Porazińskiej. Przeprowadzona analiza bibliologiczna egzemplarzy książek pisarki jednoznacznie wskazuje, iż w okresie tym nie przerwała ona pracy nad kolejnymi nowymi tytułami, jednak ówczesna sytuacja uniemożliwiła ich opublikowanie. Stało się to realne dopiero po 1945 roku. Było tak m. in. w przypadku powieści Borówka. Mimo iż pierwsze wydanie ukazało się w 1947 r., to adnotacja autorki, umieszczona pod tekstem głównym, jasno wskazuje datę i miejsce powstania książki - „Warszawa, 1943” (s. 173). 
Okres od zakończenia wojny do śmierci pisarki w 1971 r. jest najbardziej owocny w całym jej twórczym życiu. W ciagu 26 lat ukazało się: 27 książek autorskich, 2 współautorskie oraz 5 przetłumaczonych z innych języków (ostatnie - szóste tłumaczenie trafiło na księgarskie półki dopiero dwa lata po śmierci pisarki), co daje łącznie 34 tytuły.

Okres powojenny otwiera więc wydawanie książek Porazińskiej powstałych podczas wojny. Z całkowitą pewnością można wymienić dwa takie tytuły - wspomnianą Borówke oraz poemat Była sobie gqska. Czy było ich więcej? Nie sposób dziś ustalić. Do końca lat 40. ukazało się siedem nowych książek Porazińskiej (wśród nich jedna pozycja współautorska), a dekada kolejna lata 50. XX w. - przynosi apogeum jej twórczości potwierdzone przez wydanie 22 tytułów autorskich, 1 współautorskiego i 4 tłumaczeń. W latach 1953, 1957 i 1958 ukazało się po 5 pozycji, w roku 1955 - 4, w 1952 - 3, w 1950 i 1954 - po 2, a w 1959 - 1. W okresie tym Porazińska zaangażowała się w opracowywanie tłumaczeń książek autorów zagranicznych, głównie skandynawskich, co, być może, miało podłoże w licznych zagranicznych podróżach, $\mathrm{m}$. in. do krajów Skandynawii, które pisarka odbyła w dwudziestoleciu międzywojennym (Głodkowska, 1963, s. 4). Ostatnią dekadą twórczej działalności Porazińskiej (lecz kolejna jej ogromnej, rosnącej popularności) były lata 60 . XX w., kiedy to oddała do druku 6 książek -5 autorskich i jedno tłumaczenie. Jej ostatnią autorską pozycją był Pamietnik Czarnego Noska, drukowany na łamach czasopisma „Słonko” w latach 1935-1937, a w 1964 r. wydany w formie książkowej. Jeszcze później, bo w 1969 r., opublikowano przedostatnią przetłumaczona przez nią książkę - Skrzat z. zamku w Abo Z. Topeliusa, a ostatnią, która ukazała się za jej życia. Porazińska miała wówczas 87 lat.

\section{Wydawcy książek Janiny Porazińskiej}

L Autorka $W$ Wojtusiowej izbie przekazywała czytelnikom swoje nowe książki w latach 1912-1969, czyli przez 57 lat. Nieoceniona jest rola wydawców, którzy zaangażowali się w publikowanie utworów Porazińskiej, umożliwiając im ujrzenie światła dziennego. Za życia pisarka nawiązała współpracę z 36 oficynami, spośród których trzy - M. Arct, „Nasza Księgarnia” i „Czytelnik" - moga pochwalić się znacznymi, w porównaniu do pozostałych wydawnictw, zasługami w popularyzowaniu książek Porazińskiej.

Niewatpliwie wydanie pierwszej książki umożliwiły pisarce kontakty nawiązane przez nią z „Przyjacielem Dzieci”, bowiem właśnie redakcja tego pisemka opublikowała w 1912 r. debiutancką baśń sceniczną $W$ noc wiosennq. Zanim utwory autorki Szewczyłka Dratewki zaczęła wydawać w 1918 r. oficyna Michała Arcta, wychodziły one nakładem drukarni Władysława Lazarskie- 
go, Księgarni Polskiej i Księgarni Ludowej Julii Sikorskiej, które przekazały czytelnikom odpowiednio - 2, 1 i 4 tytuły.

Rok 1918 był dla Porazińskiej poczattkiem udanej, bo aż trzydziestoletniej współpracy $z$ wydawnictwem Michała Arcta. Ta księgarnia, założona w Lublinie w 1836 r. przez Stanisława Arcta, a od 1852 r. prowadząca również wydawnictwo, za znaczący obszar działalności obrała sobie popularyzację książki dziecięcej i młodzieżowej. Za jej przyczyną ukazywało się czasopismo dla najmłodszych „Moje Pisemko” (Birkenmajer \& Kocowski \& Trzynadlowski, red., 1971), w którym Porazińska drukowała swoje teksty w latach 1906-1924. Te koneksje prawdopodobnie ułatwiły jej rozpoczęcie współpracy z oficyna M. Arcta, pod szyldem której w latach 1918-1948 ukazało 12 książek pisarki w 29 edycjach. Wydawnictwo opublikowało kilka ważnych i popularnych, jak się później okaże, tytułów Porazińskiej, m. in. WW Wojtusiowej izbie (1924), Kichuś Majstra Lepigliny (1924), Wesoła gromada (1933) czy Kozucha Kłamczucha (1939). Największą aktywność w wydawaniu książek pisarki oficyna przejawiała w latach 1923-1929, 1936-1939 oraz 1945-1948. Dziewiąte wydanie zbiorku W Wojtusiowej izbie było ostatnia pozycją Porazińskiej, którą wydrukowała firma Michała Arcta.

Od wydania przez Michała Arcta pierwszej książki pisarki do rozpoczęcia przez nią w 1929 r. współpracy z drugim poważnym wydawcą - „Naszą Księgarnia” - utwory Porazińskiej publikowało siedem mniejszych oficyn: „Oświata”, Księgarnia J. Lisowskiej, Polski Czerwony Krzyż, Wydawnictwo Czasopisma dla Dzieci i Młodzieży „Płomyk”, Bibljoteka Polska, Wielkopolski Związek Kół Śpiewaczych oraz K. S. Jakubowski. Spośród nich wydawnictwa: K. S. Jakubowskiego i Bibljoteka Polska opublikowały największa liczbę pozycji (odpowiednio - 9 i 7). Stało się to głównie za sprawą wydawania przez nie elementarzy i czytanek oraz ich kolejnych wznowień.

Założone w 1921 r. przez Związek Nauczycielstwa Polskiego Wydawnictwo „Nasza Księgarnia” kierowało swoją ofertę do nauczycieli, dzieci i młodzieży, publikując materiały metodyczne, podręczniki oraz książki dla młodych czytelników. Jego nakładem ukazywały się ważne i popularne czasopisma, takie jak „Płomyk” czy „Płomyczek” (Tamże), których współzałożycielka i wieloletnią autorką była Janina Porazińska. „Nasza Księgarnia” stała się największym i najwierniejszym wydawcą książek pisarki, bowiem również obecnie pod szyldem „NK” ukazuja się jej pozycje. W ciagu 84 lat (1929-2013) oficyna opublikowała 31 książek Porazińskiej w 137 edycjach. Ta długa historia rozpoczęła się wydaniem w 1929 r. Kopciuszka i choć okres międzywojenny oraz lata wojny przyniosły zaledwie pojedyncze pozycje opublikowane przez tę oficynę, to po roku 1945 „Nasza Księgarnia” stała się głównym wy- 
dawcą książek pisarki. Jej nakładem drukowano pierwodruki i kolejne wznowienia wielu książek, a 15 tytułów ukazało się wyłącznie pod szyldem „NK”, np. Jaś i Kasia (8 wydań w latach 1933-1987), Agata noga zamiata (7 edycji w latach 1953-1967), Kacperek (1954-1969 - 7 wznowień), Zuchwaly strayżyk (9 wydań w latach 1955-1989). Książki pisarki pojawiły się w ramach 9 serii wydawniczych, m. in. „Czytam Sam”, „Poczytaj mi, Mamo”, „Lektura Szkolna”, „Moje Książeczki”, „Klasyka Dziecięca”, a ostatnio - „Moje Poczytajki”. W okresie całego PRL można wymienić zaledwie pięć lat (1949, 1968, 1975, 1977, 1980), kiedy nakładem „Naszej Księgarni” nie ukazała się ani jedna książka Porazińskiej. Również obecnie oficyna nie zapomniała o pisarce nadal wydawane sa pojedyncze jej pozycje (głównie wznowienia Szewczyka Dratewki).

Po roku 1929, czyli rozpoczęciu współpracy z „NK”, autorka $W W$ ojtusiowej izbie drukowała swoje utwory u kolejnych 11 wydawców, których udział w popularyzacji jej twórczości był jednak niewielki. Spośród nich aż 7 oficyn wydało zaledwie po jednej książce, pozostałe 3 - po dwie pozycje. I dopiero rok 1945 przyniósł kolejna - trzecią i zarazem ostatnią na tak dużą skalę - bardzo owocną wspólpracę Porazińskiej. Nawiązała ona wówczas kontakt z założonym zaraz po wojnie „Czytelnikiem”, czego rezultatem było wydanie 13 ksiazżek w 41 edycjach na przestrzeni 43 lat (1945-1988). Największym przedsięwzięciem było opublikowanie w latach 1957-1986 czternastu z piętnastu edycji powieści Kto mi dat skerzydła. „Czytelnik” miał również swoisty „monopol” na tytuł I w sto koni nie dogoni... Gaweda o moim drieciństwie (5 edycji między 1961 a 1988 rokiem). Największą aktywność w wydawaniu książek Porazińskiej oficyna ta wykazywała w latach 1956-1970, kiedy to nieprzerwanie ukazało się łącznie 28 pozycji pisarki. Ostatnią wydaną pod szyldem „Czytelnika” była piąta edycja I w sto koni nie dogoni... z 1988 r.

Między ukazaniem się pierwszej książki nakładem „Czytelnika” a śmiercią pisarki w 1971 r., Porazińska publikowała utwory u kolejnych 11 wydawców, jednak wśród nich było tylko kilka, które opublikowały więcej niż jedna, dwie pozycje: Państwowe Wydawnictwa Muzyczne (4 utwory w 6 edycjach), Polskie Wydawnictwo Muzyczne (5 tytułów w 9 wydaniach) i „Ruch” (3 książki, 7 wznowień). Dwie pierwsze oficyny drukowały teksty wierszowane z nutami.

Po śmierci Porazińskiej jej utwory ukazywały się nadal nakładem „Naszej Księgarni” i „Czytelnika”, choć ten drugi wydawca przestał publikować książki pisarki po 1988 roku. Zmiany ustrojowe, które nastapiły po roku 1989, również na rynku wydawniczym, widać wyraźnie na przykładzie wydawnictw publikujących pozycje Porazińskiej. W latach 1991-1999 książki pisarki pojawiaja się w ofercie dziesięciu nowo powstałych oficyn, a w pierwszych la- 
tach XXI w. publikuja je jeszcze trzy kolejne oficyny. Tak więc w latach 19712013 utwory Porazińskiej ukazywały się pod szyldem 14 wydawców, chociaż ponad połowa z nich - aż 8 - opublikowało zaledwie jedną pozycję. Większą inicjatywą wydawniczą wykazały się: Krajowa Agencja Wydawnicza (4 tytuly w 8 edycjach), GMP (3 pozycje), „Lektura” (2 książki), „Editions Spotkania” (1 tytuł w 2 wydaniach), „Siedmioróg” (4 książki w 11 wznowieniach), „Literatura" (2 pozycje w 3 edycjach) oraz "Zielona Sowa” (1 tytuł w 3 wydaniach).

\section{Wznowienia}

L Na przestrzeni 101 lat (1912-2013) książki Janiny Porazińskiej publikowało 50 wydawców i choć tylko troje spośród nich - M. Arct, „Nasza Księgarnia”, „Czytelnik” - zaangażowało się bardziej we współpracę z pisarką, to gdyby nie - często jednorazowe i okazjonalne - inicjatywy pozostałych 47 oficyn, dorobek wydawniczy autorki $S_{\text {zewczy }}$ a Dratewki z pewnością nie byłby tak okazały i imponujący. Łącznie bowiem nakładem wszystkich wydawców ukazały się 332 publikacje Janiny Porazińskiej, a wśród nich: 299 wznowień książek autorskich, 21 edycji publikacji współautorskich i 12 wydań pozycji przetłumaczonych. Próba ustalenia ostatecznej liczby wszystkich wznowień książek Porazińskiej okazała się zadaniem niełatwym i z całkowita pewnością nie można stwierdzić, czy się powiodła. Trudności te związane sa $\mathrm{m}$. in. z kwestią numeracji kolejnych wydań stosowanej przez wydawnictwa. Jako jeden z przykładów może posłużyć książka Kichuś Majstra Lepigliny. Tytuł ten doczekał się 16 wznowień na przestrzeni lat 1924-1997. Zastanawiający jest fakt, że dwa wydania tej książki zostały oznaczone numerem 4 - jedno przez wydawnictwo M. Arcta, drugie przez „Naszą Księgarnię” - a brak jest wydania trzeciego. Nie wiadomo, czy edycja 3 w ogóle się ukazała, lecz nie odnotowały jej żadne bibliografie i katalogi biblioteczne, czy też w oficynie M. Arcta pomylono numerację (albo było to działalnie celowe). Jeszcze bardziej skomplikowana sytuacja jest w przypadku zbiorku $W W_{o j-}$ tusiowej iz̨bie. Na przestrzeni 68 lat (1924-1992) ukazały się 22 edycje tomiku. Wydawnictwo M. Arcta, które rozpoczęło wydawanie tego tytułu, stosowało numerację konsekwentnie, aż do ostatniego - ósmego - wznowienia. W międzyczasie, jak odnotowuje katalog Biblioteki Narodowej, pojawiła się edycja, o której wiadomo tylko tyle, że wydano ją w roku 1930 - miejsce wydania ani wydawca nie sa znane; żadne inne katalogi i bibliografie nie odnotowuja tej pozycji. Ponadto, w 1943 r. w Nowym Jorku „Roy Publishers” publikuje edycję 2 zbiorku, chociaż o pierwszej - wydanej przez to wydawnictwo - nic nie wiadomo. I kwestia ostatnia - w 1956 r. „Czytelnik” rozpoczyna wydawanie 
$W$ Wojtusiowej iąbie, oznaczając swoja pierwszą edycję numerem 5 , co wydaje się niemożliwe do wyjaśnienia. Weryfikacja tego typu niejasności w różnych źródłach doprowadziła ostatecznie do ustalenia wspomnianej wyżej liczby wydań i na jej podstawie dokonane zostały dalsze analizy.

Pierwsze wznowienia autorskich książek Porazińskiej pojawiały się już w latach 20. XX wieku. Okres dwudziestolecia międzywojennego można nazwać stopniowym wkraczaniem na rynek wydawniczy publikacji pisarki, gdyż w ciagu tych dwóch dekad ukazało się 45 edycji jej książek, odpowiednio 22 i $23 \mathrm{w}$ każdym z dziesięcioleci.

O ile w czasie trwania wojny nie ukazał się żaden nowy tytuł Porazińskiej, to w latach 1942-1945 do czytelników trafiło 8 kolejnych wznowień. Były to pozycje wydawane w większości za granicami kraju, m. in. w Nowym Jorku (przez oficynę „Roy Publishers”), Budapeszcie (przez Wydawnictwo Biblioteki Polskiej w Budapeszcie), na Bari i w Jerozolimie (przez sekcje wydawnicze stacjonujących tam polskich korpusów). Po wojnie, do końca lat 40. ukazało się jeszcze 20 wznowień.

Dwie ostatnie dekady życia pisarki, czyli lata 50. i 60. XX w., charakteryzuje osiagnięcie silnej pozycji jej książek na rynku wydawniczym, wyrażone liczbą kolejnych edycji. Wówczas pojawiło się ich aż 115, a w poszczególnych dekadach odpowiednio - 61 i 45. Należy przypomnieć, że lata 50 . były również najbardziej owocne pod względem wydawania nowości.

Trzy kolejne dziesięciolecia po śmierci autorki - od lat 70. do 90. XX w. - można określić jako utrwalenie się stałej obecności książek Porazińskiej na rynku wydawniczo-księgarskim. Wydano wówczas 75 edycji jej książek, w każdej z dekad odpowiednio - 23, 24 i 28. Dopiero XXI w. przyniósł znaczący spadek popularności książek pisarki, choć nie zapomniano o nich zupełnie. W pierwszym dziesięcioleciu XXI w. ukazało się 14 pozycji, a w pierwszych latach drugiej dekady - 2010-2013 - było ich 8, co daje nadzieję, że ostateczna liczba w całej dekadzie zbliży się do tej z pierwszego dziesięciolecia XXI wieku.

Ważną kwestia jest wskazanie tytułów, które doczekały się największej liczby wznowień. Pierwsze miejsce w tym rankingu zajmuje baśń $S$ zewczyle Dratewkea, która zaczęła ukazywać się samodzielnie od 1973 r., już po śmierci Porazińskiej, a w roku 2013 „Nasza Księgarnia” wydała jej 28 edycję. Na drugiej pozycji plasuje się zbiór wierszy Psotki i śmiesそki z 26 wznowieniami opublikowanymi na przestrzeni lat 1955-2011. Wspomniany wcześniej tomik $W W$ ojtusiowej iz̧bie wydany 22 razy jest trzecią z kolei książka pod względem liczby kolejnych wydań. Następne miejsca zajmują: baśń Kichuś majstra Lepigliny, która ukazała się szesnastokrotnie oraz Kto mi dat skerzydta wydane 15 
razy. Prawie wszystkie te książki - z wyjątkiem $W$ W ojtusiowej iąbie - były lekturami szkolnymi, co oczywiście tłumaczy tak liczne wznowienia.

Kolejną interesującą kwestią dotyczącą książek Janiny Porazińskiej są wielkości ich nakładów. Badania własne autorki niniejszego artykułu pozwoliły ustalić łączną liczbę egzemplarzy 113 książek pisarki, która wynosi 8179343. Dane te pochodza z metryczek publikacji badanych z autopsji lub z opisów w katalogach bibliotecznych. Najmniejszy nakład - 8400 egzemplarzy- miało wydanie $W W$ ojtusiowej iźbie z 1951 roku. Jest to jedyna z badanych pozycji wydana w nakładzie mniejszym niż 10 tys. egzemplarzy. W nakładzie między 10 a 20 tys. egzemplarzy ukazało się 13 książek, natomiast najwięcej, bo aż 45 pozycji mieści się w następnym przedziale $-25-50$ tys. egzemplarzy. Dwadzieścia trzy książki wydano w 60-90 tys. egzemplarzy, trzynaście - w około 100 tys. egzemplarzy, cztery - w około 150 tys. egzemplarzy, pięć - w około 200 tys. egzemplarzy. i trzy - w 300 tys. egzemplarzy. Największe nakłady osiagnęły dwa opowiadania wydane w ramach serii "Poczytaj mi, Mamo” - Agata noga ramiata z 1967 r. i Niebieska driewcrynka z 1985 r. - odpowiednio 375235 i 375300 egzemplarzy. Ponadto, tytuły te maja największy ogólny nakład - odpowiednio 1150990 i 825694 egzemplarzy.

Informacje o nakładach książek Janiny Porazińskiej podaje również „Ruch Wydawniczy w Liczbach” za 2012 rok. Wskazuje on, iż 201 wydań ksiązek pisarki, opublikowanych w latach 1944-2012, osiagnęło łączny nakład 10959000 egzemplarzy (Seroka, red., 2013). W publikacji wskazano także najczęściej wydawane książki Porazińskiej i wielkości ich produkcji wydawniczej. Według tych danych na pierwszym miejscu jest zbiór wierszy Psotki $i$ śmieszki, którego 22 edycje ukazały się w 1129000 egzemplarzy, następnie - piętnaście edycji Kto mi dat skerzydła - w 981 tys. egzemplarzy i dwadzieścia jeden wznowień Szewczyka Dratewki - w 602 tys. egzemplarzy (Tamże). Ogólna liczba prawie 11 milionów egzemplarzy świadczy o ogromnej produkcji wydawniczej książek Porazińskiej i lokuje ją w jednej grupie z takimi autorami dla dzieci, jak Maria Kownacka czy Adam Bahdaj.

\section{Ilustratorzy}

L Istotnym elementem książki dziecięcej są ilustracje, oddziałujące na sferę emocjonalną i poznawczą młodych czytelników. Ważna jest więc osoba artysty-plastyka zaangażowanego w tworzenie szaty graficznej, będącego w stanie dokonać jak najlepszej interpretacji tekstu, dostosowanej do specyficznego, w tym przypadku, odbiorcy. 
Liczba 93 książek Janiny Porazińskiej i 332 wznowień tychże pociaga za soba proporcjonalnie rzeszę ilustratorów tekstów pisarki - było ich bowiem 65. Należy zaznaczyć, że za życia pisarka nawiązała współpracę z 44 spośród nich, natomiast pozostałych 21 ilustrowało wydania ukazujące się już po śmieci autorki $W$ Wojtusiowej į̧bie. Przygoda większości tych grafików z książkami Porazińskiej była jednak niezwykle krótka i często jednorazowa. Aż 51 stworzyło szatę graficzną zaledwie do jednego tytułu, ale należy nadmienić, że w prawie połowie $\mathrm{z}$ tych przypadków dany tytuł miał kilka wznowień w tej samej szacie graficznej. Dla przykładu: Zofia Stryjeńska jest autorką ilustracji tylko do poematu Jaś i Kasia, jednak na przestrzeni lat 1933-1987 wszystkie edycje wydano właśnie w tej jednej interpretacji ilustratorskiej. Podobnych przypadków jest jeszcze 23.

Obok dużej liczby ilustratorów ,jednego tytułu” jest mniej liczna grupa 14 artystów, którzy zinterpretowali dwie lub więcej książek Janiny Porazińskiej. Dolna granicę osiagnęli tacy graficy, jak: Antoni Gawiński, Maria Gabryś-Orłowska, Jan Marcin Szancer, Eugenia Różańska, a wśród współczesnych - Jarosław Żukowski i Aneta Krella-Moch. Po trzy tytuły zilustrowali: Ludwik Maciag, Bożena Truchanowska i Adam Kilian, jednak dopiero pięć następnych nazwisk to te, które mają największe zasługi na polu plastycznych interpretacji książek Porazińskiej. Olga Siemaszko stworzyła szaty graficzne do 4 tytułów, które ukazały się w 13 edycjach; po 5 książek (wydanych w 14 wznowieniach) zilustrowali Zbigniew Rychlicki i Bogdan Zieleniec; Stanisław Bobiński zinterpretował 10 tytułów, a jego rysunki zamieszczono w 25 wznowieniach, a Michał Bylina ( $\mathrm{z}$ którym pisarka przez wiele lat pracowała w „Płomyczku”, a potem w „Słonku”) stworzył szatę graficzną do 11 książek wydanych w 26 edycjach. Z pięcioma artystami wymienionymi na końcu Porazińska nawiązała współpracę za życia i widać, że nie bez przyczyny pojawiły się w tym gronie tak znane nazwiska. Można wnioskować bowiem, że pisarka, świadoma roli ilustracji w książce dziecięcej, tak dobierała grafików, by ze swoich książek tworzyć pozycje wartościowe również pod względem wizualnym.

W kwestii ilustracji pojawia się aspekt tytułów najchętniej interpretowanych. I tak jak w przypadku największej liczby wznowień na pierwszym miejscu znajduje się baśń Szewczyke Dratewka, tak i w rankingu najczęściej ilustrowanych tytułów zajmuje tą samą pozycję. Na przestrzeni 40 lat (19732013) szaty graficzne do 28 edycji tego tytułu stworzyło ośmiu plastyków. Młodzi czytelnicy mogą więc podziwiać malarskie, utrzymane w baśniowym stylu ilustracje Bogdana Zieleńca, przypominające dziecięce bazgroły rysunki Michała Grejnieca, subtelne kreski Anny Stylo-Ginter, czy wreszcie (zbyt) groteskowe - Jarosława Żukowskiego. Zależność między liczbą wydań 
i wielością interpretacji ilustratorskich nie jest jednak reguła, gdyż zbiór Psotki $i$ śmieszk ki, który był drugi pod względem liczby wznowień, został zilustrowany zaledwie przez trzech artystów. Dużym zainteresowaniem grafików cieszyła się natomiast książka Kichuś majstra Lepigliny zinterpretowana pięciokrotnie i na wiele sposobów - począwszy od surowych, realistycznych rysunków Michała Byliny, przez szkicowe, delikatne Marii Orłowskiej-Gabryś, aż do groteskowych Jacka Skrzydlewskiego. Z liczbą czterech wersji ilustratorskich trzecie miejsce w tym swoistym rankingu zajmuje zbiór $W$ Wojtusiowej iz̨bie. Również tutaj można podziwiać niezwykłą różnorodność w sposobie interpretacji. Mamy więc czarno-białe szkicowe rysunki Stanisława Bobińskiego, dekoracyjne i jednocześnie subtelne ryciny wykonane techniką druku wypukłego autorstwa Marii Orłowskiej, bajkowe ilustracje Olgi Siemaszko oraz baśniowe, okraszone humorem rysunki Elżbiety Krygowskiej-Butlewskiej.

Stworzenie tak wielu różnych interpretacji ilustratorskich do tych samych książek może być potwierdzeniem pisarskiego kunsztu Porazińskiej. Za pomocą słów potrafiła wykreować świat pełen kolorów, dźwięków, kształtów, który pobudza dziecięca fantazję, ale i wyobraźnię artystów, umożliwiając im tworzenie tak różnorodnych szat graficznych.

Pisarskie dokonania Janiny Porazińskiej i wydawniczy sukces jej książek czynia z niej literacki fenomen. 103 lata obecności na rynku wydawniczym, 93 wydane tytuły w 332 edycjach, 50 wydawców i 65 ilustratorów zaangażowanych w pracę nad pozycjami autorki, to liczby, które wzbudzaja podziw i szacunek. Czy Porazińska jest więc autorka jeszcze popularną czy już zapomnianą? Ograniczając się do faktu, iż w XXI w. ukazały się 22 kolejne edycje jej książek, można stwierdzić, że całkowicie o niej nie zapomniano. Warto wspomnieć o jeszcze jednej kwestii - ciagłej obecności tekstów Porazińskiej w antologiach poezji dziecięcej, zbiorach baśni i legend. Ogromna produkcja wydawnicza publikacji tego typu, którą można współcześnie obserwować, uniemożliwia podanie konkretnej liczby antologii, w których znajdują się utwory pisarki; autorka niniejszego teksu dotarła do 11, wydanych tylko po 2000 r., przypuszczalnie jest ich więcej.

Czy jednak można mówić o trwającej wciąż popularności Janiny Porazińskiej, skoro niewielu kojarzy jej nazwisko, choć większość zna napisane przez nia w 1924 r. słowa kołysanki: „Na Wojtusia z popielnika iskiereczka mruga..."? Wydaje się więc, że sama pisarka nie jest już popularna, ale i nie jest jeszcze zapomniana, a niektóre jej teksty weszły na stałe do kanonu literatury dla dzieci i młodzieży i prawdopodobnie jeszcze długo w nim pozostaną. 


\section{Bibliografia}

Białek, Józef Zbigniew. (1963). Janiny Porazińskiej poezja dla dzieci. Rocznik Naukowo-Dydaktyczny WSP w Krakowie. Prace Historyczno-Literackie, 17, 195-222.

Białek, Józef Zbigniew. (1987). Literatura dla dzieci $i$ mtodzieży w latach 1918-1939. Zarys monograficzny. Materiaty. Warszawa: Wydaw. Szkolne i Pedagogiczne.

Białkowska, Barbara. (1957). O twórczości Janiny Porazińskiej. Poradnik Bibliotekarza $, 2,42-45$.

Birkenmajer, Aleksander \& Kocowski, Bronisław \& Trzynadlowski, Jan. (red.) (1971). Encyklopedia wiedzy o ksiażce. Wrocław, Warszawa, Kraków: Zakład Narodowy im. Ossolińskich.

Czachowska, Jadwiga \& Szałagan, Alicja. (red.) (1999). Wspótcześni polscy pisarz̧e $i$ badacze literatury. Stownik biobibliograficzny. T. 6. Warszawa: Wydaw. Szkolne i Pedagogiczne.

Frycie, Stanisław. (red.) (1982). Literatura dla dzieci i mtodzie zy w latach 1945-1970. T. 2: Baśn i bajka, poezja, ksiazki dla najmłodszych, utwory sceniczne, grafika, czasopismiennictwo, krytyka literacka. Warszawa: Wydaw. Szkolne i Pedagogiczne.

Frycie, Stanisław \& Ziółkowska-Sobecka, Marta. (1999). Leksykon literatury dla dzieci i młodzieży. Piotrków Trybunalski: Wydaw. Filii Kieleckiej WSP.

Daniszewski, Brunon. (1989). Janina Porazinska pisarka dla dzieci i młodziézy. Toruń: Wojewódzka Biblioteka Publiczna i Książnica Miejska im. M. Kopernika w Toruniu.

Głodkowska, Zofia. (1963). Podwójny jubileusz. Głos Nauczycielski, 39, 4.

Lewandowicz-Nosal, Grażyna. (2012). Obecna czy nieobecna? Wznowienia książek Janiny Porazińskiej w XXI wieku. Wychowanie w Prz̨edszkolu, 2.

Olszewska, Bożena. (2007). „I w sto koni nie dogoni...”. O życiu i sztuce pisarskiej Janiny Porazinskiej. Opole: Wydaw. Uniwersytetu Opolskiego.

Olszewska, Bożena. (2014). „Kto mi dat skrzydła...”. O życiu i działalności Janiny Porazińskiej. Opole: Wydaw. Uniwersytetu Opolskiego.

Pacholarz, Małgorzata. (2014). Dzieje wydawnicze twórczości Janiny Porazińskiej. Lódź: Uniwersytet Łódzki, praca mgr pod kier. dr hab. prof. UŁ J. Koniecznej.

Pietrzak, Jan. (1996). Janina Porazińska na Ziemi Sieradzkiej. Siódma Prowincja, 3, 27-28.

Porazińska, Janina. (1947). Borówka. Warszawa: Warszawska Spółdzielnia Wydawnicza „Syrena”.

Ratyńska, Hanna. (2011). Czy nastąpi renesans twórczości Janiny Porazińskiej? Na Powiślu, 21, 10-11.

Seroka, Anna. (red.) (2013). Ruch Wydawniczy w Licz̧bach 2012. Warszawa: Biblioteka Narodowa - Zakład Statystyki Wydawnictw. Pobrane 13 września 2015, z: http://www.bn.org.pl/download/document/ 1377611929.pdf/

Tylicka, Barbara \& Leszczyński, Grzegorz. (red.) (2002). Stownik literatury dzieciecej i młodzieżowej. Wrocław, Warszawa, Kraków: Zakład Narodowy im. Ossolińskich. 


\section{Janina Porazińska - author still popular or already forgotten? From the history of publishing books writer}

ABSTRACT: The aim of this article is to present the history of publishing works of Janina Porazińska and answer the question of whether Porazińska is still a popular writer or already forgotten one. The first part introduces the character of the artist and outlines the development of her literary workshop. Moreover, it presents the current state of research on the person and work of Porazińska. The second part contains a discussion on the history of publishing works of the writer; presents statistical data relating to new titles and their next releases, supplemented with a bibliological comment. The article includes an attempt of the periodization of the popularity of writer's books. It also discusses the publishing institutions and illustrators involved in work with Porazińska's books. The author portrays the literary phenomenon of the writer whose books have been on the publishing market for 103 years now.

KEYWORDS: Janina Porazińska, Polish publishers, Polish children's literature 